\title{
Reclassification of Bacillus haloalkaliphilus Fritze 1996 as Alkalibacillus haloalkaliphilus gen. nov., comb. nov. and the description of Alkalibacillus salilacus sp. nov., a novel halophilic bacterium isolated from a salt lake in China
}

\author{
Correspondence \\ Chang-Jin Kim \\ changjin@kribb.re.kr
}

\author{
Che Ok Jeon, ${ }^{2}$ Jee-Min Lim, ${ }^{1}$ Jung-Min Lee, ${ }^{1}$ Li-Hua $\mathrm{Xu}^{3}$ \\ Cheng-Lin Jiang ${ }^{3}$ and Chang-Jin Kim ${ }^{1}$ \\ ${ }^{1}$ Korea Research Institute of Bioscience and Biotechnology, 52 Oeundong, Yusong, Daejeon \\ 305-333, Republic of Korea \\ ${ }^{2}$ Environmental Biotechnology National Core Research Center, Division of Environmental \\ Biotechnology, Gyeongsang National University, 660-701, Korea \\ ${ }^{3}$ Yunnan Institute of Microbiology, Yunnan University, Kunming, Yunnan, 650091, P. R. China
}

Moderately halophilic bacteria that grow optimally in media containing 3-15\%(w/v) $\mathrm{NaCl}$ are widely distributed in different saline habitats such as salterns, estuarine water, salt lakes, salty foods, sea ice and deep-sea hydrothermal vents. These micro-organisms are taxonomically very diverse and are spread over each of the three domains: Archaea, Bacteria and Eucarya (Oren, 2002). They are also metabolically diverse. Aerobic, spore-forming, moderately halophilic, Gram-positive rods are also taxonomically diverse and have been isolated from marine environments and related habitats. They were originally assigned to the genus Bacillus,

Published online ahead of print on 29 April 2005 as DOI 10.1099/ ijs.0.63456-0.

The GenBank/EMBL/DDBJ accession number for the 16S rRNA gene sequence of strain $\mathrm{BH}_{163}{ }^{\top}$ is $\mathrm{AY} 671976$.

An electron micrograph of strain $\mathrm{BH} 163^{\top}$ and a table detailing cellular fatty acid compositions for strain $\mathrm{BH} 163^{\top}$ and related type strains are available as supplementary material in IJSEM Online. but they have been reclassified as new genera by the application of molecular methods and improved phenotypic approaches (Heyndrickx et al., 1999; Spring et al., 1996; Wainø et al., 1999; Yoon et al., 2001, 2004).

In the course of screening halophilic bacteria, an aerobic Gram-positive, obligately halophilic bacterium, designated strain $\mathrm{BH} 163^{\mathrm{T}}$, was isolated from soil sediment of a salt lake. Comparative analysis of $16 \mathrm{~S}$ rRNA gene sequences indicated that the closest relative of the strain was [Bacillus] haloalkaliphilus $\mathrm{WN}_{13}{ }^{\mathrm{T}}$ (95.9\% $16 \mathrm{~S}$ rRNA gene sequence similarity), which was classified as a novel species within the genus Bacillus (Fritze, 1996). However, we found that strain WN13 should be reclassified in a new genus on the basis of phylogenetic and phenotypic characteristics. Therefore, we propose the reclassification of [Bacillus] haloalkaliphilus in the new genus Alkalibacillus as Alkalibacillus haloalkaliphilus gen. nov., comb. nov., with $\mathrm{WN}^{2} 3^{\mathrm{T}}$ as the type strain. A novel species, Alkalibacillus salilacus sp. nov., type strain $\mathrm{BH} 163^{\mathrm{T}}$, is also described. 
Strain $\mathrm{BH} 163^{\mathrm{T}}$ was isolated from soil sediment of Ai-Ding Lake in Xin-jiang province in China. Ai-Ding Lake is a typical chloride-sulphate saline lake with a neutral $\mathrm{pH}$ and a $20-26 \%$ (w/v) salt concentration. Surface soil sediment was sampled from a shallow area of the lakeside. To isolate halophilic bacteria, soil sediment was serially diluted, spread on marine agar 2216 (MA; Difco) supplemented with $15 \%$ $(\mathrm{w} / \mathrm{v}) \mathrm{NaCl}$ [final concentration $16.94 \% \mathrm{NaCl}(\mathrm{w} / \mathrm{v})]$ and incubated for 5 days at $28^{\circ} \mathrm{C}$. Requirement for and tolerance of $\mathrm{NaCl}$ were determined in tryptic soy broth (TSB) supplemented with modified artificial sea water [ASW; 0-30\% (w/v) $\mathrm{NaCl}, 5.94 \mathrm{~g} \mathrm{MgSO}_{4} .7 \mathrm{H}_{2} \mathrm{O}, 4.53 \mathrm{~g} \mathrm{MgCl}_{2} \cdot 6 \mathrm{H}_{2} \mathrm{O}$, $0.64 \mathrm{~g} \mathrm{KCl}$ and $1.3 \mathrm{~g} \mathrm{CaCl}_{2}$ per litre]. The strain was routinely grown aerobically on MA containing $10 \%(\mathrm{w} / \mathrm{v})$ $\mathrm{NaCl}$ for 3 days at $30^{\circ} \mathrm{C}$ except where indicated otherwise. Anaerobic growth was determined by incubation in an anaerobic chamber at $30^{\circ} \mathrm{C}$ for 5 days on MA containing $10 \%(\mathrm{w} / \mathrm{v}) \mathrm{NaCl}$. Optimum growth was tested at different temperatures $\left(4-55^{\circ} \mathrm{C}\right)$ on MA containing $10 \%(\mathrm{w} / \mathrm{v}) \mathrm{NaCl}$ and at different $\mathrm{pH}$ values $(5 \cdot 0-10 \cdot 0)$ in TSB supplemented with ASW containing $10 \%(\mathrm{w} / \mathrm{v}) \mathrm{NaCl}$.

Cell morphology was studied using light and transmission electron microscopy (TEM). Motility was observed at 24 and $48 \mathrm{~h}$ in agar-coated wet mounts using a light microscope (Nikon E600). Each agar-coated wet mount was prepared by placing $10 \mu \mathrm{l}$ culture under a cover glass on a glass slide that had previously been coated with a film of $0.5 \%(\mathrm{w} / \mathrm{v})$ agarose (Cambrex) in distilled water and airdried. For visualization of flagella, cells were mounted on Formvar-coated copper grids (Electron Microscopy Science) and negatively stained with $2 \%(\mathrm{w} / \mathrm{v})$ uranyl acetate for $15 \mathrm{~s}$ and then subjected to TEM (JEM-1010; JEOL). Endospores were stained according to the method of Schaeffer-Fulton (Smibert \& Krieg, 1981).

Catalase activity was determined by the production of oxygen bubbles in $3 \%(\mathrm{v} / \mathrm{v})$ aqueous hydrogen peroxide solution. Oxidase activity was tested by the oxidation of $1 \%$ $(\mathrm{w} / \mathrm{v})$ tetramethyl- $p$-phenylenediamine (Merck). Hydrolysis of aesculin, casein, starch, Tween 80 , urea, hypoxanthine, tyrosine, gelatin and xanthine was determined on MA according to previously described methods (Cowan \& Steel, 1965; Lanyi, 1987; Smibert \& Krieg, 1994). Nitrate reduction was performed according to Lanyi (1987). Acid production from carbohydrates was tested as described by Leifson (1963); all suspension media were supplemented with ASW containing $10 \%(\mathrm{w} / \mathrm{v}) \mathrm{NaCl}$.

GC analysis of fatty acid methyl esters was performed with cells grown on MA containing 5 or $10 \%(\mathrm{w} / \mathrm{v}) \mathrm{NaCl}$ for 3 days at $30^{\circ} \mathrm{C}$ according to the manufacturer's instructions for the Microbial Identification System (MIDI; Microbial ID). Preparation of cell walls from the test strain and analyses of peptidoglycan structures were carried out using the methods described by Schleifer (1985) with the modification that TLC was performed on cellulose sheets instead of using paper chromatography. Isoprenoid quinones were analysed as described by Komagata \& Suzuki (1987) using an HPLC fitted with a reverse-phase column (GROM-SIL 100 ODS-2FE; GROM). The DNA G + C content of strain $\mathrm{BH} 163^{\mathrm{T}}$ was determined by reverse-phase HPLC according to Tamaoka \& Komagata (1984).

The 16S rRNA gene was amplified by PCR using Eubac $27 \mathrm{~F}$ and $1492 \mathrm{R}$ primers (DeLong, 1992) and sequenced. The resulting sequences were compared with available $16 \mathrm{~S}$ rRNA gene sequences from GenBank using the BLAST program (http://www.ncbi.nlm.nih.gov/blast/) to determine the approximate phylogenetic affiliation and then aligned with closely related members by using CLUSTAL W software (Thompson et al., 1994). Sequence similarity values were computed using the Similarity Matrix tool, version 1.1 (Ribosomal Database Project II; http://35.8.164.52/html/; Cole et al., 2003). Gaps at the $5^{\prime}$ - and $3^{\prime}$-ends of the alignment were omitted from further analyses. The phylogenetic trees were constructed using three different methods, neighbour-joining (Saitou \& Nei, 1987), maximumlikelihood (Felsenstein, 1981) and maximum-parsimony (Fitch, 1971), using algorithms available in PHYLIP software, version 3.6 (Felsenstein, 2002). For the neighbour-joining method, evolutionary distance matrices were calculated according to the Kimura two-parameter model (Kimura, 1980). To evaluate the stability of the phylogenetic tree, a bootstrap analysis (1000 replications) was performed with the SEQBOOT, DNADIST, NEIGHBOR and CONSENSE programs in the PHYLIP software package.

Strain $\mathrm{BH} 163^{\mathrm{T}}$ showed moderate halophilic properties, growing in media containing 5-20\% (w/v) NaCl; optimum growth occurred in media with $10-12 \%(\mathrm{w} / \mathrm{v}) \mathrm{NaCl}$. Colonies of the strain were cream, smooth, low-convex and circular/slightly irregular on MA containing $10 \%(\mathrm{w} / \mathrm{v})$ $\mathrm{NaCl}$. Growth was observed at temperatures between 15 and $40{ }^{\circ} \mathrm{C}$, with an optimum growth temperature of $30^{\circ} \mathrm{C}$. Cells of the isolate were slender, strictly aerobic and motile rods (width of $0 \cdot 4-0.5 \mu \mathrm{m}$ and length $1 \cdot 6-3.0 \mu \mathrm{m}$ ) with peritrichous flagella (see Supplementary Fig. S1 in IJSEM Online).

Strain $\mathrm{BH} 163^{\mathrm{T}}$ grew well in the slightly alkaline conditions of $\mathrm{pH} 7 \cdot 0-9 \cdot 0$ in TSB containing $10 \%(\mathrm{w} / \mathrm{v}) \mathrm{NaCl}$; optimal growth was observed at $\mathrm{pH} 8 \cdot 0$. [Bacillus] haloalkaliphilus DSM $5271^{\mathrm{T}}$, the previously determined closest relative based on 16S rRNA gene sequence similarities, also grows at concentrations of up to $25 \% \mathrm{NaCl}$ and shows good growth at relatively high $\mathrm{pH}(\mathrm{pH} \mathrm{9.7)} \mathrm{(Fritze,} \mathrm{1996).} \mathrm{The} \mathrm{isolate}$ produced a spherical terminal endospore with a swollen sporangium, as found in the phylogenetically close species [Bacillus] haloalkaliphilus and Filobacillus milosensis. Growth was not observed after 5 days of incubation under anaerobic conditions at $30^{\circ} \mathrm{C}$ on MA with $10 \%(w / v) ~ N a C l$.

Strain $\mathrm{BH} 163^{\mathrm{T}}$ was catalase-positive, oxidase-negative and reduced nitrate to nitrite. Gram reaction and $\mathrm{KOH}$ tests of cells from early and late growth phases were positive and negative, respectively. However, it has been reported that [Bacillus] haloalkaliphilus and F. milosensis 
show Gram-negative reactions despite having been described as Gram-positive bacteria by Fritze (1996) and Schlesner et al. (2001) and confirmed by our tests. The analysis of cell-wall peptidoglycan showed that strain $\mathrm{BH} 163^{\mathrm{T}}$ possessed Al $\gamma$-type peptidoglycan with mesodiaminopimelic acid ( $m$-DAP) as the diagnostic diamino acid, which was identical to that of [Bacillus] haloalkaliphilus. However, F. milosensis possesses the A4 $\beta$-type peptidoglycan, L-Orn-D-Glu, which clearly distinguishes strain $\mathrm{BH}_{163}{ }^{\mathrm{T}}$ from F. milosensis (Fritze, 1996; Schlesner et al., 2001).

The predominant isoprenoid quinone of strain $\mathrm{BH} 163^{\mathrm{T}}$ was menaquinone-7 (MK-7) and the $\mathrm{G}+\mathrm{C}$ content of genomic DNA was about $41 \mathrm{~mol} \%$. The cellular fatty acid profile of strain $\mathrm{BH} 163^{\mathrm{T}}$ was characterized as containing saturated branched fatty acids such as anteiso- $\mathrm{C}_{15: 0}(\sim 39 \cdot 7 \%)$, iso$\mathrm{C}_{15: 0}(\sim 30.9 \%)$, anteiso- $\mathrm{C}_{17: 0}(\sim 11 \cdot 8 \%)$ and iso- $\mathrm{C}_{16: 0}$ $(\sim 8.9 \%)$ on MA containing $10 \%(\mathrm{w} / \mathrm{v}) \mathrm{NaCl}$, which was similar to that of [B.] haloalkaliphilus (Fritze, 1996). The fatty acid profiles on MA with 5 or $10 \%(\mathrm{w} / \mathrm{v}) \mathrm{NaCl}$ were similar (see Supplementary Table S1 in IJSEM Online). The cell-wall peptidoglycan, fatty acid profiles, major lipoquinone and DNA G $+\mathrm{C}$ content of strain $\mathrm{BH} 163^{\mathrm{T}}$ were similar to those of [Bacillus] haloalkaliphilus and clearly distinguishable from those of $F$. milosensis within the group classically defined as the genus Bacillus (Fritze, 1996; Schlesner et al., 2001). The typical phenotypic and chemotaxonomic properties of strain $\mathrm{BH} 163^{\mathrm{T}}$ are summarized and compared with those of phylogenetically related type relatives in Table 1.

Comparative analysis of $16 \mathrm{~S}$ rRNA gene sequences showed that strain $\mathrm{BH} 163^{\mathrm{T}}$ was a member of the phyletic group classically defined as the genus Bacillus and was associated with 'Bacillus Group 1' (Ash et al., 1991; Nielsen et al., 1994; Schlesner et al., 2001; Stackebrandt \& Liesack, 1993). The phylogenetic analysis showed that the isolate formed a phyletic group with [Bacillus] haloalkaliphilus DSM $5271^{\mathrm{T}}$ in the neighbour-joining analysis (Fig. 1). The topologies of the phylogenetic trees built using the maximum-likelihood and maximum-parsimony algorithms were similar to that

Table 1. Characteristics of strain $\mathrm{BH}_{16} 3^{\top}$ and related species

Strains: 1, strain $\mathrm{BH}_{163} 3^{\mathrm{T}} ; 2$, Alkalibacillus haloalkaliphilus DSM $5271^{\mathrm{T}} ; 3$, Filobacillus milosensis DSM $13259^{\mathrm{T}}$; 4, Tenuibacillus multivorans NBRC $100370^{\mathrm{T}}$; 5, Bacillus halophilus DSM 4771 $;$ 6, Marinococcus albus DSM $20748^{\mathrm{T}}$; 7, Halobacillus halophilus DSM $2266^{\mathrm{T}}$. Data from Fritze (1996); Schlesner et al. (2001); Ren \& Zhou (2005); Hao et al. (1984); Ventosa et al. (1989) and Spring et al. (1996). S, Spherical; E, ellipsoidal; T, terminal; C, central; ST, subterminal; $m$-DAP, meso-diaminopimelic acid; + , positive; - , negative; w, weak; ND, no data.

\begin{tabular}{|c|c|c|c|c|c|c|c|}
\hline Characteristics & 1 & 2 & 3 & 4 & 5 & 6 & 7 \\
\hline Size $(\mu \mathrm{m})$ & $0 \cdot 4-0 \cdot 5 \times$ & $0 \cdot 3-0 \cdot 5 \times$ & $0 \cdot 3-0 \cdot 5 \times$ & $0 \cdot 3-0 \cdot 5 \times$ & $0 \cdot 5-1 \cdot 0 \times$ & $1 \cdot 0-1 \cdot 2$ & ND \\
\hline Pigmentation & Cream & Cream white & White & Translucent & None & None & Orange \\
\hline Gram reaction & + & - & - & + & + & + & + \\
\hline Spore shape & s & s & s & s & E & None & s \\
\hline $\mathrm{NaCl}$ range $(\% \mathrm{w} / \mathrm{v})$ & $5-20$ & $0-25$ & $2-23$ & $1-20$ & $3-30$ & $5-20$ & $0-25$ \\
\hline Catalase & + & + & + & + & + & + & + \\
\hline Oxidase & - & + & - & - & + & + & + \\
\hline Nitrate reduction & + & - & - & - & - & + & - \\
\hline \multicolumn{8}{|l|}{ Hydrolysis of: } \\
\hline Urea & - & - & $\mathrm{ND}$ & ND & + & + & - \\
\hline \multicolumn{8}{|l|}{ Acid production from: } \\
\hline D-Glucose & - & - & - & - & - & - & - \\
\hline D-Fructose & $\mathrm{w}$ & ND & - & - & ND & - & - \\
\hline D-Mannitol & - & ND & - & - & - & - & - \\
\hline D-Xylose & - & - & - & - & + & - & - \\
\hline Maltose & - & ND & - & - & - & - & - \\
\hline D-Trehalose & - & - & - & - & + & - & - \\
\hline Cell-wall type & $m$-DAP & $m$-DAP & Orn-D-Glu & $m$-DAP & $m$-DAP & $m$-DAP & Orn-D-Asp \\
\hline $\mathrm{G}+\mathrm{C}$ content $(\mathrm{mol} \%)$ & 41 & $37-38$ & 35 & $36 \cdot 5-37$ & $51 \cdot 5$ & $44 \cdot 9$ & $40-41$ \\
\hline
\end{tabular}




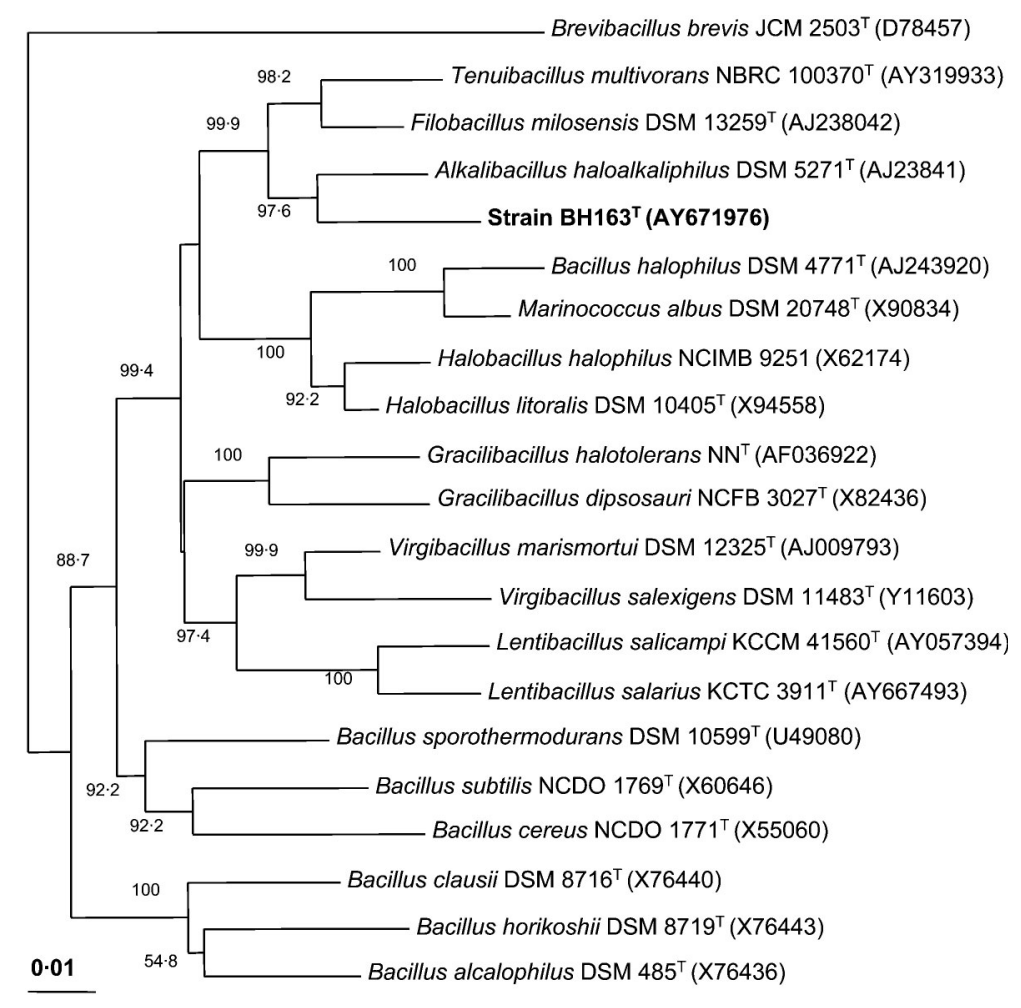

Fig. 1. Neighbour-joining tree showing the phylogenetic relationships based on $16 \mathrm{~S}$ rRNA gene sequences of strain $\mathrm{BH}_{163^{\top}}$ and other related taxa. Bootstrap values are shown in percentages of 1000 replicates, when more than $50 \%$. Brevibacillus brevis JCM $2503^{\top}$ was used as an outgroup. Bar, 0.01 changes per nucleotide position.

of the tree constructed by the neighbour-joining analysis (data not shown). The closest relative of strain $\mathrm{BH} 163^{\mathrm{T}}$ was [Bacillus] haloalkaliphilus DSM $5271^{\mathrm{T}}$ with $95 \cdot 9 \% 16 \mathrm{~S}$ rRNA gene sequence similarity, a level at which they can be considered to be in the same genus. However, strain $\mathrm{BH} 163^{\mathrm{T}}$ shared low $16 \mathrm{~S}$ rRNA gene sequence similarity of $94 \cdot 5$ and $94 \cdot 2 \%$ with two other close relatives, F. milosensis DSM $13259^{\mathrm{T}}$ and Tenuibacillus multivorans NBRC $100370^{\mathrm{T}}$, respectively.

The chemotaxonomic and molecular characteristics described here show that strain $\mathrm{BH} 163^{\mathrm{T}}$ and [Bacillus] haloalkaliphilus should be described as members of the same genus and that they are distinguishable from other closely related genera such as Filobacillus and Tenuibacillus within the group classically defined as the genus Bacillus. Therefore, we propose the reclassification of [Bacillus] haloalkaliphilus DSM $5271^{\mathrm{T}}$ to the genus Alkalibacillus as Alkalibacillus haloalkaliphilus DSM $5271^{\mathrm{T}}$ gen. nov., comb. nov. In addition, strain $\mathrm{BH} 163^{\mathrm{T}}$ represents a novel species in the genus Alkalibacillus, for which the name Alkalibacillus salilacus sp. nov. is proposed.

\section{Description of Alkalibacillus gen. nov.}

Alkalibacillus (Al.ka.li.ba.cil'lus. N.L. n. alkali alkali; L. n. bacillus rod; N.L. masc. n. Alkalibacillus bacillus living under alkaline conditions).

Cells are Gram-variable, spore-forming rods. Catalasepositive. Urease-negative. Spherical endospores are formed terminally in swollen sporangia. Strictly aerobic and moderately halophilic. Cells are motile by means of peritrichous flagella. Cell-wall peptidoglycan is of the A1 $\gamma$ type with meso-DAP as the diagnostic diamino acid. Major isoprenoid quinone is MK-7. DNA G $+\mathrm{C}$ content is 38$41 \mathrm{~mol} \%$ (HPLC). Predominant cellular fatty acids are iso$\mathrm{C}_{15: 0}$, anteiso- $\mathrm{C}_{15: 0}$ and anteiso- $\mathrm{C}_{17: 0}$. Phylogenetically, the genus belongs to the family Bacillaceae. The type species of the genus is Alkalibacillus haloalkaliphilus ( $=$ DSM $5271^{\mathrm{T}}$ ).

\section{Description of Alkalibacillus haloalkaliphilus (Fritze 1996) comb. nov.}

Alkalibacillus haloalkaliphilus (hal.o.al.ka.li'phi.lus. Gr. n. hals salt; N.L. n. alkali alkali; Gr. adj. philos loving; N.L. masc. adj. haloalkaliphilus loving briny and alkaline media).

Basonym: Bacillus haloalkaliphilus Fritze 1996.

Gram reaction is negative. Catalase- and oxidase-positive. Nitrate not reduced to nitrite. Cells are $0 \cdot 3-0 \cdot 5 \mu \mathrm{m}$ wide and 3-8 $\mu \mathrm{m}$ long. On alkaline nutrient agar supplemented with $5-10 \%(\mathrm{w} / \mathrm{v}) \mathrm{NaCl}$, colonies are cream white. In the presence of $20 \%$ (w/v) NaCl, colonies are slightly yellowish. The major cellular fatty acids are the saturated branched chain fatty acids iso- $\mathrm{C}_{15: 0}(48 \%)$, anteiso- $\mathrm{C}_{15: 0}(11 \%)$, anteiso- $\mathrm{C}_{17: 0}(11 \%)$ and iso- $\mathrm{C}_{17: 0}(6 \%)$. A small amount (19\%) of unsaturated fatty acids is also present. Chemoorganotrophic. Does not grow (or grows only very poorly) in nutrient broth or on nutrient agar without $\mathrm{NaCl}$. Mesophilic. Obligately alkaliphilic. No growth occurs at $\mathrm{pH} 7$ and good growth occurs at $\mathrm{pH} 9 \cdot 7$. Hydrolysis of starch is weak and no, or only weak, hydrolysis of casein occurs. Gelatin 
and hippurate are hydrolysed. Pullulan, Tween 20, Tween 80 and 4-methylumbelliferone glucuronide are not hydrolysed. Egg yolk lecithinase and urease tests are negative. The DNA G $+\mathrm{C}$ content is $38.0 \mathrm{~mol} \%$ (HPLC).

The type strain, $\mathrm{WN} 13^{\mathrm{T}}\left(=\mathrm{DSM} 5271^{\mathrm{T}}=\mathrm{ATCC} 700606^{\mathrm{T}}=\right.$ CIP $106702^{\mathrm{T}}=\mathrm{JCM} 12303^{\mathrm{T}}=$ LMG $\left.17943^{\mathrm{T}}\right)$, was isolated from alkaline, highly saline mud from Wadi Natrun, Egypt.

\section{Description of Alkalibacillus salilacus sp. nov.}

Alkalibacillus salilacus (sa.li.lac'us. L. n. sal salt; L. n. lacus lake; N.L. gen. masc. n. salilacus of a salt lake).

Colonies are cream, smooth, low-convex and circular/ slightly irregular. Cells are approximately $0 \cdot 4-0 \cdot 5 \mu \mathrm{m}$ wide and $1 \cdot 6-3 \cdot 0 \mu \mathrm{m}$ long. Strictly aerobic, spore-forming, motile rod. Gram-positive. $\mathrm{KOH}$ test negative. Catalasepositive and oxidase-negative. Nitrate is reduced to nitrite. Growth occurs at $15-40{ }^{\circ} \mathrm{C}$ (optimum $30^{\circ} \mathrm{C}$ ), $\mathrm{pH} 7 \cdot 0-9 \cdot 0$ (optimum $\mathrm{pH} 8 \cdot 0$ ) and $5-20 \%(\mathrm{w} / \mathrm{v}) \mathrm{NaCl}$ (optimum $10-12 \%)$. Aesculin is hydrolysed. Hydrolysis of casein, starch, Tween 80, L-tyrosine, hypoxanthine, xanthine, gelatin and urea is not observed. Acids are produced from L-arabinose, D-ribose, $\alpha$-D-lactose and D-fructose, but not from D-glucose, maltose, glycerol, D-trehalose, D-xylose, L-rhamnose, adonitol, D-raffinose, D-mannitol, arbutin, D-salicin, D-melibiose or D-mannose. DNA G + C content is $41.0 \mathrm{~mol} \%$ (HPLC). Predominant cellular fatty acids are anteiso- $\mathrm{C}_{15: 0}$, iso- $\mathrm{C}_{15: 0}$, anteiso- $\mathrm{C}_{17: 0}$ and iso- $\mathrm{C}_{16: 0}$.

The type strain, $\mathrm{BH} 163^{\mathrm{T}}\left(=\mathrm{KCTC} 3916^{\mathrm{T}}=\mathrm{DSM} 16460^{\mathrm{T}}\right)$, was isolated from a salt lake in the Xin-jiang province of China.

\section{Acknowledgements}

This work was supported by the 21C Frontier Microbial Genomics and Application Center Program, Ministry of Science \& Technology (grant MG05-0101-1-0) and the International Cooperation R\&D Program, Ministry of Science \& Technology (grant M6-0203-00-0002), Republic of Korea.

\section{References}

Ash, C., Farrow, J. A. E., Wallbanks, S. \& Collins, M. D. (1991). Phylogenetic heterogeneity of the genus Bacillus as revealed by comparative analysis of small-subunit ribosomal-RNA sequences. Lett Appl Microbiol 13, 202-206.

Cole, J. R., Chai, B., Marsh, T. L. \& 8 other authors (2003). The Ribosomal Database Project (RDP-II): previewing a new autoaligner that allows regular updates and the new prokaryotic taxonomy. Nucleic Acids Res 31, 442-443.

Cowan, S. T. \& Steel, K. J. (1965). Manual for the Identification of Medical Bacteria. London: Cambridge University Press.

DeLong, E. F. (1992). Archaea in coastal marine environments. Proc Natl Acad Sci U S A 89, 5685-5689.

Felsenstein, J. (1981). Evolutionary trees from DNA sequences: a maximum likelihood approach. J Mol Evol 17, 368-376.
Felsenstein, J. (2002). PHYLIP (Phylogeny Inference Package), version 3.6a. Distributed by the author. Department of Genome Sciences, University of Washington, Seattle, WA, USA.

Fitch, W. M. (1971). Toward defining the course of evolution: minimum change for a specific tree topology. Syst Zool 20, 406-416. Fritze, D. (1996). Bacillus haloalkaliphilus sp. nov. Int J Syst Bacteriol 46, 98-101.

Hao, M. V., Kocur, M. \& Komagata, K. (1984). Marinococcus gen. nov., a new genus for motile cocci with meso-diaminopimelic acid in the cell wall; and Marinococcus albus sp. nov. and Marinococcus halophilus (Novitsky and Kushner) comb. nov. J Gen Appl Microbiol 30, 449-459.

Heyndrickx, M., Lebbe, L., Kersters, K., De Vos, P., Forsyth, G. \& Logan, N. A. (1999). Virgibacillus: a new genus to accommodate Bacillus pantothenticus (Proom and Knight 1950). Emended description of Virgibacillus pantothenticus. Int J Syst Bacteriol 48, 99-106.

Kimura, M. (1980). A simple method for estimating evolutionary rates of base substitutions through comparative studies of nucleotide sequences. J Mol Evol 16, 111-120.

Komagata, K. \& Suzuki, K. (1987). Lipid and cell-wall analysis in bacterial systematics. Methods Microbiol 19, 161-208.

Lanyi, B. (1987). Classical and rapid identification methods for medically important bacteria. Methods Microbiol 19, 1-67.

Leifson, E. (1963). Determination of carbohydrate metabolism of marine bacteria. J Bacteriol 85, 1183-1184.

Nielsen, P., Rainey, F. A., Outtrup, H., Priest, F. G. \& Fritze, D. (1994). Comparative $16 \mathrm{~S}$ rDNA sequence analysis of some alkaliphilic bacilli and the establishment of a sixth rRNA group within the genus Bacillus. FEMS Microbiol Lett 117, 61-66.

Oren, A. (2002). Diversity of halophilic microorganisms: environments, phylogeny, physiology, and applications. I Ind Microbiol Biotechnol 28, 56-63.

Ren, P. -G. \& Zhou, P. -J. (2005). Tenuibacillus multivorans gen. nov., sp. nov., a moderately halophilic bacterium isolated from saline soil in Xin-Jiang, China. Int J Syst Evol Microbiol 55, 95-99.

Saitou, N. \& Nei, M. (1987). The neighbor-joining method: a new method for reconstructing phylogenetic trees. Mol Biol Evol 4, 406-425.

Schleifer, K. H. (1985). Analysis of the chemical composition and primary structure of murein. Methods Microbiol 18, 123-156.

Schlesner, H., Lawson, P. A., Collins, M. D., Weiss, N., Wehmeyer, U., Völker, H. \& Thomm, M. (2001). Filobacillus milensis gen. nov., sp. nov., a new halophilic spore-forming bacterium with Orn-D-Glutype peptidoglycan. Int J Syst Evol Microbiol 51, 425-431.

Smibert, R. M. \& Krieg, N. R. (1981). General characterization. In Manual of Methods for General Microbiology, pp. 409-443. Edited by P. Gerhardt, R. G. E. Murray, R. N. Costilow, E. W. Nester, W. A. Wood, N. R. Krieg \& G. B. Phillips. Washington, DC: American Society for Microbiology.

Smibert, R. M. \& Krieg, N. R. (1994). Phenotypic characterization. In Methods for General and Molecular Bacteriology, pp. 607-654. Edited by P. Gerhardt, R. G. E. Murray, W. A. Wood \& N. R. Krieg. Washington, DC: American Society for Microbiology.

Spring, S., Ludwig, W., Marquez, M. C., Ventosa, A. \& Schleifer, K.-H. (1996). Halobacillus gen. nov., with description of Halobacillus litoralis sp. nov. and Halobacillus trueperi sp. nov., and transfer of Sporosarcina halophila to Halobacillus halophila comb. nov. Int J Syst Bacteriol 46, 492-496.

Stackebrandt, E. \& Liesack, W. (1993). Nucleic acids and classification. In Handbook of New Bacterial Systematics, pp. 152-189. Edited by M. Goodfellow \& A. G. O’Donnell. London: Academic Press. 
Tamaoka, J. \& Komagata, K. (1984). Determination of DNA base composition by reverse-phase high-performance liquid chromatography. FEMS Microbiol Lett 25, 125-128.

Thompson, J. D., Higgins, D. G. \& Gibson, T. J. (1994). CLUSTAL W: improving the sensitivity of progressive multiple sequence alignment through sequence weighting, position-specific gap penalties and weight matrix choice. Nucleic Acids Res 22, 4673-4680.

Ventosa, A., Garcia, M. T., Kamekura, M., Onishi, H. \& RuizBerraquero, F. (1989). Bacillus halophilus sp. nov., a moderately halophilic Bacillus species. Syst Appl Microbiol 12, 162-165.

Wainø, M., Tindall, B. J., Schumann, P. \& Ingvorsen, K. (1999). Gracilibacillus gen. nov., with description of Gracilibacillus halotolerans gen. nov., sp. nov.; transfer of Bacillus dipsosauri to
Gracilibacillus dipsosauri comb. nov., and Bacillus salexigens to the genus Salibacillus gen. nov., as Salibacillus salexigens comb. nov. Int J Syst Bacteriol 49, 821-831.

Yoon, J. H., Weiss, N., Lee, K. C., Lee, I. S., Kang, K. H. \& Park, Y. H. (2001). Jeotgalibacillus alimentarius gen. nov., sp. nov., a novel bacterium isolated from jeotgal with L-lysine in the cell wall, and reclassification of Bacillus marinus Rüger 1983 as Marinibacillus marinus gen nov., comb. nov. Int J Syst Evol Microbiol 51, 2087-2093.

Yoon, J. H., Oh, T. K. \& Park, Y. H. (2004). Transfer of Bacillus halodenitrificans Denariaz et al. 1989 to the genus Virgibacillus as Virgibacillus halodenitrificans comb. nov. Int J Syst Evol Microbiol 54, 2163-2167. 